\title{
Unsur Kearifan Lokal Masyarakat Atoni Pah Meto Dalam Legenda Oepunu
}

\author{
Metropoly Merlin J. Liubana ${ }^{1}$
}

\author{
Ibrahim Nenohai ${ }^{2}$ \\ Program Studi Pendidikan Bahasa dan Sastra Indonesia, Fakultas Ilmu \\ Pendidikan, Universitas Timor ${ }^{1}$, SMA Negeri Santian² \\ ${ }^{1}$ mmerlin2007@gmail.com \\ ${ }^{2}$ nifukliko@gmail.com
}

\begin{abstract}
Abstrak
Kebudayaan lokal suatu masyarakat, erat kaitannya dengan tradisi masyarakat itu sendiri. Seperti yang terangkum dalam legenda Oepunu. Pengkajian terhadap legenda Oepunu dilakukan untuk mendeskripsikan kearifan lokal masyarakat Atoni Pah Meto di Kabupaten Timor Tengah Selatan. Penelitian ini bersifat deskriptif kualitatif dengan data primer berupa cerita rakyat legenda Oepunu yang dikumpulkan dari informan. Pengumpulan data dilakukan dengan teknik mengobservasi, merekam, dan mencatat. Kemudian data dianalisis secara deskriptif dengan langkah mentranskripsikan data ke bentuk teks, mengidentifikasi, mengklasifikasikan, menginterpretasikan, dan mengeksploitasi dalam penguraian secara detail dengan pendekatan mimesis dan teori kearifan lokal. Hasil penelitian menunjukkan kearifan lokal yang terbagi menjadi beberapa hal yaitu: pengetahuan sebagai peramal (mnane); hasil keterampilan lokal berupa esu, mau dan tais: solidaritas kelompok lokal berupa budaya mamat dan tarian bonet; kepercayaan Uis Pah, dan Uis Neno; Marga sebagai Identitas Masyarakat Atoni Pah Meto yang terdiri atas marga Tusi, Tano, Leobanu, dan Ana Bansoma; Latar berupa Oekbiti, Putu, Oepunu, Kono; dan faut esu sebagai peninggalan.
\end{abstract}

Kata Kunci: kearifan lokal, legenda Oepunu

\section{Pendahuluan}

Sastra lisan adalah bagian dari kebudayaan, memiliki nilai-nilai positif yang tumbuh dan hidup di tengah masyarakat pendukungnya. Dikatakan demikian karena sastra lisan merupakan refleksi perilaku sehari-hari dalam kehidupan masyarakat pendukungnya yang meliputi budaya, pola pikir, dan pandangan hidup (Siyono, 2014: 55). Sastra daerah juga termasuk bagian dari folklor yang dalam pengertiannya sebagai sebagian kebudayaan suatu kolektif yang tersebar dan diwariskan turun-temurun, di antara kolektif macam apa saja, secara tradisional dalam versi yang berbeda, baik dalam bentuk lisan maupun contoh yang disertai gerak isyarat maupun alat pembantu pengingat, Danandjaja (2007:2). Sebagai salah satu jenis sastra lisan, cerita rakyat merupakan ekspresi budaya suatu masyarakat melalui bahasa tutur yang berhubungan langsung dengan berbagai aspek budaya dan susunan nilai masyarakat tersebut, Athaila (Maulidiah dan Saddhono, 2019:185).

Cerita rakyat menawarkan berbagai hal yang unik dan menarik untuk ditelusuri dan diungkapkan. Zaidan berpandangan bahwa, cerita rakyat daerah dalam konteks sastra lisan di Indonesia merupakan kekayaan budaya daerah yang kehidupannya sangat 
tergantung pada pendukung budaya daerah yang bersangkutan. Sebagai salah satu sumber yang menyimpan nilai-nilai kedaerahan, cerita rakyat sangat penting bagi keberagaman budaya di Indonesia. Cerita rakyat sebagai karya sastra memiliki nilai budaya dan fungsi sebagai cermin dan pedoman masyarakatnya, (Indrastuti, 2018:191).

Legenda Oepunu merupakan salah satu cerita rakyat yang terdapat di Desa Billa, Kecamatan Amanuban Timur, Kabupaten Timor Tengah Selatan. Legenda Oepunu memiliki kisah asal usul penamaan sumber air berupa kolam yang terletak di dekat sungai Benenai batas wilayah Kabupaten Timor Tengah Selatan dengan Kabupaten Timor Tengah Utara. Dikategorikan legenda karena Oepunu termasuk cerita yang menggambarkan kekhasan budaya masyarakat Atoni Pah Meto. Seperti yang dikemukakan oleh Rusyana, dkk. (2000:39), bahwa cerita yang berjenis legenda adalah cerita yang dihubungkan dengan peristiwa dan benda pada masa lalu.

Kisah legenda Oepunu menawarkan nilai-nilai lokal yang perlu ditelusuri secara mendalam. Tradisi kebudayaan lokal dalam cerita rakyat Oepunu sangat erat kaitannya dengan kehidupan nyata masyarakat setempat. Namun dengan adanya perkembangan modern yang sangat pesat, menjadi faktor utama bergesernya nilai-nilai kearifan budaya lokal yang selama ini terpelihara. Generasi penerus mulai mengutamakan kecanggihan dan budaya pop yang diadopsi dari luar daerah dibandingkan dengan budaya asli miliknya. Padahal kearifan budaya lokal merupakan aset bangsa dan identitas masyarakat yang multikultural, (Nurjanah dan Nurdayanti, 2019:168). Oleh karena itu untuk meminimalisir krisis identitas generasi Atoni Pah Meto, perlu menambah pemahaman tentang unsur kearifan lokal melalui penelitian ini.

Haba (2007:11) berpandangan bahwa kearifan lokal mengacu pada berbagai kekayaan budaya yang tumbuh dan berkembang dalam sebuah masyarakat dan merupakan element penting untuk memperkuat kohesi sosial di antara warga masyarakat. Oleh karena itu kearifan lokal perlu dihidupkan kembali agar tidak tergeser nilai-nilai identitas diri masyarakat di tengah-tengah arus perkembangan ilmu pengetahuan yang semakin meningkat. Seperti yang tertuang dalam enam peran vital kearifan lokal antara lain: sebagai penanda identitas sebuah komunitas; elemen perekat lintas warga, agama dan kepercayaan; tidak bersifat memaksa tetapi lebih merupakan kesadaran dari dalam; memberi warna kebersamaan sebuah komunitas; dapat mengubah pola fikir dan hubungan timbal balik individu dan kelompok dan meletakkannya di atas kebudayaan yang dimilikinya; dapat mendorong proses apresiasi, partisipasi sekaligus meminimalisir anarkis yang merusak solidaritas dan integrasi komunitas (Haba, 2007:78).

Kearifan lokal juga merupakan kemampuan budaya setempat dalam menghadapi pengaruh kebudayaan asing pada waktu kebudayaan tersebut berelasi, (Nurjanah dan Nurdayanti, 2019: 168). Selain itu kearifan lokal dapat dikatakan sebagai pengetahuan asli (indigineous knowledge) atau kecerdasan lokal (local genius) suatu masyarakat yang berasal dari nilai luhur tradisi budaya untuk mengatur tatanan kehidupan masyarakat dalam rangka mencapai kemajuan komunitas baik dalam penciptaan kekeluargaan, kedamaian maupun peningkatan kesejahteraan masyarakat, Sibarani (2012:125). Begitu pula dengan pandangan Nuraini dan Alfan (2012:68-69) bahwa, local wisdom (kearifan setempat) dapat dipahami sebagai gagasan-gagasan setempat yang bersifat bijaksana, penuh kearifan, bernilai baik, yang tertanam dan diikuti oleh anggota masyarakatnya. Dengan demikian dapat dikatakan bahwa kearifan lokal merupakan gagasan dan pedoman berperilaku baik, bernilai, atau sebagai tatanan kehidupan masyarakat yang diatur dan dilaksanakan oleh masyarakat pemiliknya secara turun-temurun. 
Kearifan lokal mencakup berbagai mekanisme dan cara untuk bersikap, berperilaku dan bertindak yang dituangkan dalam tatanan sosial baik dalam bentuk seni, budaya dan bahkan kehidupan sehari-hari. Hal ini terangkum dalam dimensi-dimensi kearifan lokal yang dikemukakan oleh Ife (Sudikan, 2013:46), di antaranya: pengetahuan, nilai, keterampilan, sumber daya, mekanisme pengambilan keputusan, dan solidaritas kelompok lokal. Semua unsur itu dapat ditemukan dalam berbagai tradisi lisan salah satunya adalah dalam cerita rakyat yang dituturkan dari mulut ke mulut pergenerasi hingga kini. Demikian pula bagi masyarakat Atoni Pah Meto, kearifan budaya lokal merupakan salah satu unsur budaya yang dapat diketahui melalui prosa rakyat legenda Oepunu.

Kearifan lokal dalam legenda Oepunu merupakan fakta budaya yang tercermin dalam kehidupan masyarakat Atoni Pah Meto. Untuk mengidentifikasi fakta-fakta budaya tersebut perlu dilakukan dengan berbagai bentuk pengkajian, salah satunya dengan pengkajian Representasi kearifan lokal.

Representasi dalam konteks penelitian sastra sama dengan yang dimaksud dengan mimesis menurut Abrams (dalam Tussaadah dkk, 2020:323) yang memandang karya sastra sebagai tiruan, pencerminan, atau penggambaran dunia dan kehidupan manusia. Karya sastra, seperti bentuk-bentuk seni lainnya, secara umum sering dipandang sebagai upaya merepresentasikan kenyataan dan sastra dianggap sebagai imitasi. atau tiruan kenyataan yang ada (Budiman dalam Santosa 2011, dalam Indrastuti 2018:192). Sama halnya dengan yang dikutip dari (Nurjanah dan Darmayanti, 2019:176) bahwa teori representasi dalam karya sastra merupakan penggambaran karya sastra terhadap suatu fenomena sosial. Penggambaran ini tentu saja melalui pengarang sebagai kreator. Representasi dalam sastra muncul sehubungan dengan adanya pandangan atau keyakinan bahwa karya sastra sebetulnya hanyalah merupakan cermin, gambaran, bayangan, atau tiruan kenyataan. Sehubungan dengan hal itu, maka penulis lebih cenderung menggunakan kajian representasi kearifan lokal masyarakat Atoni Pah Meto dalam legenda Oepunu, dengan pendekatan mimesis.

Aristoteles (Semi, 2008:43) berpandangan bahwa mimesis lebih tinggi dari kenyataan ia memberi kebenaran yang lebih umum, kebenaran yang universal. Pendekatan mimetik adalah pendekatan kajian sastra yang menitikberatkan kajiannya terhadap hubungan karya sastra dengan kenyataan di luar karya sastra sebagai imitasi dan realitas (Abrams dalam Siswanto, 2008:188). Wellek Warren juga mengatakan bahwa sifat sastra memang menyajikan sebagian besar tentang kehidupan, sementara itu kehidupan dunia nyata merupakan keadaan sosial masyarakat. Dengan demikian kajian terhadap cerita legenda Oepunu dilakukan menggunakan teori kearifan lokal dalam berbagai bentuk dan fungsi dengan pendekatan mimesis untuk merepresentasikan kearifan lokal tersebut.

\section{Metode}

Penggunaan metode kualitatif sangat relevan dengan penguraian secara deskriptif dalam penelitian ini. Hal ini sesuai dengan kajian yang bersifat deskriptif berupa data tulis atau data lisan dari orang atau perilaku yang diamati, khususnya terhadap penuturan lisan legenda Oepunu. Lokasi penelitian terdapat di kecamatan Amanuban Timur Kabupaten Timor tengah Selatan. Jenis data berupa data primer dan sekunder yang diambil dari informan. Informan yang dimaksud yaitu Tetua Adat yang dalam struktur organisasi sosial sebagai orang yang memiliki kemampuan untuk menceritakan cerita rakyat tersebut. Data dikumpulkan dengan menggunakan teknik observasi, rekam, catat, 
dan wawancara Sudikan, (2001:173). Pada teknik observasi dilakukan dengan cara mengamati perilaku, adat, budaya masyarakat Atoni Pah Meto; teknik rekam menggunakan alat rekam untuk memperoleh data cerita Oepunu yang dituturkan oleh informan; dalam teknik catat dilakukan untuk mencatat hal-hal secara sekunder atau primer yang berkaitan dengan legenda Oepunu dan tradisi budaya masyarakat Atoni Pah Meto; sedangkan wawancara dilakukan secara bebas untuk mendapatkan data tambahan, terutama untuk kevalidan data. Teknik menganalisis data dilakukan dengan, mentranskripsikan data ke dalam bentuk teks; kemudian menganalisis dengan teknik mengidentifikasi, mengklasifikasikan, menginterpretasikan, dan mengeksploitasi dalam penguraian secara detail dengan pendekatan mimesis dan teori kearifan lokal.

\section{Hasil}

\section{Cerita Rakyat Legenda Oepunu}

\section{Legenda Oepunu}

(1) Terdapat sebuah sumber air berupa kolam yang diberi nama Oepunu. Kolam ini terletak di Desa Bila kecamatan Amanuban Timur, tepatnya di perbatasan kabupaten Timor Tengah Selatan dengan Timor Tengah Utara. Arah aliran air dari kolam ini mengalir masuk ke sungai besar yang disebut sungai Benanai, salah satu sungai terpanjang di Kabupaten Timor tengah Selatan. Dahulu sumber air ini bernama Oekbiti. Sumber air ini mengalir dari salah satu bukit yang bernama Putu, namun nama Oekbiti berubah menjadi Oepunu.

(2) Konon ceritanya, di atas bukit bermukimlah beberapa suku yang terdiri atas marga Tusi, Tano, Leobenu, dan Ana Bansoma dengan keluarganya masing-masing. Keempat marga inilah yang pertama bermukim di sana, mereka juga yang sebagai Pah tuaf (tuan tanah) atau orang yang dianggap memiliki kewenangan untuk mengadakan ritual onen pah (ritual yang dilakukan untuk menyembah Uis Pah (Tuhan alam) dan Uis Neno (Tuhan yang ada di langit), dengan tujuan untuk mensyukuri hasil panen yang diperoleh. Ritual syukuran itu dilakukan dalam bentuk pesta panen yang meriah.

(3) Setiap musim berkebun, keempat marga itu mengerjakan sawah, ladang di wilayah sekitar. Mereka menanam padi, jagung dan tanaman kebun lain untuk memenuhi lumbung mereka nanti. Atas keuletan kerja mereka, tanaman sawah dan ladang tumbuh subur, berbuah dan berbiji hingga siap dipanen. Mereka bersukacita atas hasil yang diperoleh sehingga diselenggarakanlah pesta panen.

(4) Pada saat pesta panen padi tiba, semua masyarakat di sekitar tempat itu pun diundang termasuk semua anggota keluarga dari keempat suku itu. Mereka berpesta ria sambil melakukan tarian Bonet yaitu tarian tradisional masyarakat Atoni Pah Meto di Timor Tengah Selatan. Dengan adanya tarian bonet yang ramai karena diiringi syair lagu, gerakkan kaki dan tangan dalam gandengan satu sama lain, akhirnya mengundang tamu-tamu yang semakin banyak.

(5) Tamu-tamu yang hadir itu merupakan jelmaan buaya-buaya dari kolam di sekitar sawah mereka. Buaya-buaya itu keluar dan berubah wujud menjadi wanita-wanita cantik dan priapria tampan serta berpakaian pesta yang mewah, menghadiri pesta tersebut.

(6) Buaya-buaya yang telah berubah wujud itu disambut ramah oleh pemilik pesta, kemudian tamu tersebut disuguhkan sirih, pinang (mpuah) atau yang dikenal dengan budaya mamat. Setelah itu mereka diajak untuk turut menari bersama-sama tanpa merasa curiga sedikit pun. Bahkan orang-orang yang terbuai oleh kesenangan semakin bahagia dihadiri tamu-tamu tak diundang yang cantik dan tampan rupawan.

(7) Pada saat pesta berlangsung, pemilik pesta menyiapkan hidangan untuk menjamu semua tamu dalam kebiasaan makan bersama. Lalu tamu jelmaan buaya tersebut diajak untuk makan bersama. Namun ajakan tuan pesta itu ditolak oleh manusia-manusia jelmaan buaya tersebut. Mereka tidak bersedia makan bersama, bahkan mereka memilih untuk pamit pulang karena malam semakin larut. Tanpa paksaan pemilik pesta membiarkan tamu tak 
diundang itu pergi, sedangkan orang-orang yang masih berpesta terus melanjutkan acara makan bersama sampai acara pesta pun usai. Pada akhirnya mereka semua terlelap dalam kelelahan dan suka-cita.

(8) Ketika semua orang tertidur lelap, buaya-buaya itu kembali dan menggigit semua orang yang tertidur sampai meninggal. Keesokan harinya ketika fajar menyingsing keluarga yang tidak ikut pesta panen semalam pun datang. Alangkah terkejutnya mereka karena mendapati semua keluarga mereka yang berpesta panen beberapa hari yang sampai semalam telah meninggal dalam keadaan tubuh yang mengganaskan, dan dengan darah yang menggenangi tempat tersebut sampai mengaliri sungai, bahkan hewan ternak peliharaan masyarakat setempat seperti kerbau, dan sapi pun telah membusuk. Aroma busuk dari bangkai manusia dan hewan tersebut sangat menyengat. Orang-orang yang mendapati hal itu pun menjadi histeris, lalu bingung serta bertanya-tanya siapakah yang membunuh anggota keluarga mereka.

(9) Dalam keadaan bingung mereka pun mencari Mnane (dukun) untuk meramal siapa pelakunya. Setelah menemukan seorang mnane, peramal itu pun melakukan ramalannya dengan menerawang keadaan sekitar, lalu dia mangatakan bahwa "ini bukan manusia yang membunuh, ini pasti Uis Oe (buaya) pelakunya.

(10) Setelah mendapat jawaban dari mnane, mereka masih kurang percaya dan ingin mengetahui kebenaran sesungguhnya. Apakah benar buaya-buayalah yang menggigit dan memangsa keluarga mereka dengan ganas hingga meninggal? Akhirnya mereka mencari cara yang tepat untuk mencari tahu hal tersebut.

(11) Mereka membungkus beberapa esu (lesung) alat menumbuk padi atau jagung bose dengan mau dan tais (kain tenun) sedemikian rupa hingga menyerupai manusia. Dan ketika malam tiba, mereka menempatkan esu yang sudah dibentuk seperti manusia itu di pintu-pintu rumah dengan posisi tidur, sedangkan mereka bersembunyi dan tidur di dalam.

(12) Pada saat tengah malam, datanglah beberapa ekor buaya dan menggigit lesung itu. Rupanya buaya-buaya itu kecewa karena tidak mendapatkan apa yang diinginkan sehingga buayabuaya itu pun pergi.

(13) Keesokan harinya orang-orang itu mendapati bekas gigitan buaya dengan tanda tertinggalnya gigi taring buaya. Mereka pun ketakutan dan berkata "Ini bukan manusia tetapi buaya, kita tidak bisa melawannya”. Kemudian mereka semua sepakat untuk pindah dari tempat tersebut. Mereka pindah ke Kono dan menetap di sana. Kono adalah salah satu tempat yang terletak di kecamatan Amanuban Selatan.

(14) Demikian sumber air itu berubah nama menjadi Oepunu yang terdiri dari dua suku kata dalam bahasa Meto yakni oe artinya air dan punu artinya busuk. Hal ini sesuai dengan peristiwa pembunuhan pada pesta panen yang mengakibatkan orang-orang meninggal dan menjadi busuk. Sedangkan lesung yang disimpan sebagai umpan untuk mencari tahu apakah orang-orang yang terbunuh itu ulah manusia atau buaya tersebut masih berupa batu yang diberi nama Faut Esu yang artinya batu dari lesung.

(15) Akhirnya sumber air kolam yang mengalir itu disebut Oepunu sampai sekarang dan di sebelah selatan beberapa ratus meter dari sumber air itu terdapat Faut Esu yang artinya batu dari lesung dan masih tersimpan sampai sekarang.

\section{M. J. Liubana dan I. Nenohai}

\section{Kearifan Lokal Masyarakat Atoni Pah Meto dalam Legenda Oepunu}

Unsur kearifan lokal masyarakat Atoni Pah Meto yang terdapat dalam legenda Oepunu berupa beberapa unsur yang berfungsi sebagai penanda identitas di antaranya, pengetahuan meramal yang disebut mnane; hasil keterampilan berupa esu (lesung) sebagai peralatan mengelola bahan makanan, mau dan tais (kain tenun); penanda solidaritas dalam tarian bonet dan budaya mamat (makan sirih pinang); kepercayaan terhadap Uis Neno (Penguasa langit) dan Uis Pah (Penguasa alam); Marga (Tusi, Tano, Leobenu, Ana Bansoma) sebagai penanda identitas; latar tempat (Oekbiti, Putu, Oepunu, Kono) sebagai unsur kearifan lokal masyarakat Atoni Pah Meto. 


\section{a. Pengetahuan Meramal (Mnane)}

Mnane (dukun/peramal) sebagai salah satu bentuk pengetahuan lokal yang terepresentasi dalam legenda Oepunu. Mnane adalah orang yang dipercaya memiliki kharisma untuk meramal kehidupan orang lain baik itu dari segi medis seperti penyebab orang sakit; dari segi kehidupan bermasyarakat itu sendiri, seperti penyebab terjadinya peristiwa yang merugikan kehidupan seseorang misalnya kematian, pertengkaran, bencana alam, bahkan masa depan orang lain. Mnane juga dianggap tabib atau dukun bagi masyarakat Atoni Pah Meto, misalnya membantu wanita hamil pada saat proses melahirkan, meracik ramuan obat tradisional untuk menyembuhkan orang sakit.

Dengan adanya Mnane, masyarakat yang mengalami musibah akan mencari dan menanyakan penyebabnya, sehingga posisi Mnane bagi masyarakat sangat dihargai. Hal itu tertuang dalam data cerita legenda Oepunu, bagian (9) dan (10).

Berdasarkan penggalan cerita bagian (9) dan (10), diketahui bahwa peran Mnane (dukun/peramal) menjadi sangat penring ketika terjadi peristiwa pembantaian oleh buaya-buaya terhadap manusia di kampung tersebut. Mnane meramalkan bahwa pembantaian itu dilakukan oleh buaya yang buas pada saat mereka sedang tidur setelah melakukan pesta panen, sehingga mereka tidak menyadari kebuasan buaya yang mencabik semua orang yang berada di tempat tersebut. Dengan adanya ramalan dari Mnane, saudara-saudara korban pun mencari cara untuk membuktikan. Setelah menjebak buaya dan mengatahui kalau ramalan dukun benar, maka mereka pun yakin bahwa Mnane adalah orang yang mampu melihat dan meramalkan kehidupan mereka. Representasi fungsi mnane bagi masyarakat Atoni Pah Meto di Timor Tengah Selatan pada zaman dahulu bukan saja sebagai peramal tetapi dapat juga menyembuhkan orang sakit dengan ramuan tradisional, sebagai dukun yang membantu ibu melahirkan. Namun pada masa sekarang Mnane dapat digantikan oleh tokoh-tokoh agama yang pandai menyembuhkan orang sakit dengan tradisi keti/naketi.

\section{b. Hasil Keterampilan berupa Esu (Lesung), Mau dan Tais (Kain Tenun)}

Setiap kelompok masyarakat pada setiap daerah memiliki keterampilan masingmasing. Di daerah Timor, khususnya pada Masyarakat Atoni Pah Meto di Timor Tengah Selatan pun memiliki keterampilan berupa kerajinan tangan yang dapat menghasilkan kain tenun, anyaman, peralatan rumah tangga, dan ukiran. Dalam legenda Oepunu ditemukan adanya dua hasil keterampilan lokal masyarakat Atoni Pah Meto yaitu esu (lesung), mau dan tais (kain tenun).

\section{Esu (Lesung)}

Esu (lesung) yaitu alat yang dibuat sebagai wadah untuk menumbuk padi atau jagung. Esu terbuat dari kayu batang pohon yang dipotong sekitar $1 \mathrm{~m}$, kemudian dilubangi hingga dalamnya sekitar $20 \mathrm{~cm}$ sampai $35 \mathrm{~cm}$. Esu (lesung) bagi masyarakat Atoni Pah Meto merupakan salah satu alat utama dalam mengelola bahan pangan. Selain lesung alat untuk menumbuk padi atau jagung ada pula alu yang dalam bahasa Meto disebut hanu. Antara lesung dengan alu memilki hubungan yang sangat erat jika hanya ada lesung maka jagung atau padi tidak dapat diubah menjadi beras atau jagung bose, demikian pula sebaliknya, jika tdak ada alu maka hasil berupa beras atau jagung bose tidak ada.

Esu (lesung) dapat dijumpai di setiap rumah masyarakat Atoni Pah Meto terutama di desa-desa. Hal itu disebabkan karena setiap rumah tangga memiliki ladang perkebunan yang menghasilkan jenis pangan padi dan jagung sehingga masyarakat dituntut untuk 
menggunakan alat penumbuk lesung dan alu dalam membersihkannya. Padi ditumbuk menggunakan lesung akan menghasilkan beras yang siap dimasak, demikian pula dengan jagung. Makanan khas masyarakat Atoni Pah Meto pada umumnya adalah jagung bose yaitu jagung yang ditumbuk di esu untuk memisahkan isi dari kulit ari biji jagung yang kering kemudian dibersihkan dan dimasak sampai empuk dengan tambahan bahanbahan yang lain. Esu (lesung) terdapat dalam cerita Oepunu, namun penggunaannya dalam cerita yang dikisahkan berbeda, yakni esu digunakan untuk membuktikan ramalan mnane dengan menjebak buaya-buaya yang memangsa orang-orang di tempat tersebut. Seperti yang tertuang dalam data cerita Legenda Oepunu bagian (11).

Seperti itulah lesung digambarkan dalam cerita Oepunu, bahwa lesung digunakan untuk menjebak buaya. Lesung dibungkus dengan mau dan tais yang merupakan pakaian tradisional masyarakat Atoni Pah Meto kemudian diletakan di pintu dengan pososi tidur.

\section{Mau dan Tais}

Pakaian tradisional setiap daerah dapat menunjukan ciri khas daerah itu. Seperti yang terdapat di Kabupaten Timor Tengah Selatan, pakaian tradisional masyarakat Atoni Pah Meto pada umumnya laki-laki memakai selimut (mau) dan baju, sedangkan perempuan memakai sarung (tais) dan kebaya. Mau wajib dikenakan oleh setiap laki-laki terutama dalam acara-acara adat maupun keagamaan. Mau terbuat dari benang yang ditenun oleh kaum perempuan Meto. Bentuk mau yaitu berukuran lebar sekitar $1 \mathrm{~m}$ sampai $1,5 \mathrm{~m}$, dan panjangnya sekitar $2 \mathrm{~m}$ sampai $3 \mathrm{~m}$. Sedangkan tais (sarung) terbuat dari benang yang ditenun bentuknya seperti kain sarung yang ujung-ujungnya dijahit hingga tersambung, sehingga mudah dikenakan kaum perempuan karena cara pemakaiannya dililitkan di pinggang atau di dada.

Pemakaian mau (selimut) pada dasarnya dikenakan oleh kaum laki-laki dengan melilitkan di pinggang yang berjumlah satu atau dua bahkan tiga jika dalam acara adat. Kemudian diikat dengan futu' (ikat pinggang) yang terbuat dari perak atau dari benang hasil tenunan dengan ukuran yang kecil dan panjang. Representasi tais sebagai pakaian perempuan meto dan mau sebagai pakaian laki-laki terdapat dalam legenda Oepunu, namun dalam hal ini digunakan sebagai pembungkus lesung untuk menjebak buaya. Seperti yang tertuang dalam data cerita legenda Oepunu bagian (11). Saat membungkus lesung, diupayakan agar persis seperti manusia yang sedang tidur, hal itu untuk mengelabui buaya-buaya tersebut.

Kain tenun mau dan tais yang teridentifikasi dalam cerita legenda Oepunu, sebagai representasi hasil menenun kaum wanita di Desa Billa Keamatan Amanuban Timur, Kabupaten Timor Tengah Selatan, dengan berbagai jenis motif, bentuk, ukuran, warna dasar, dan bahan dasar. Kain tenun tersebut sebagai penciri lokalitas masyarakat Atoni Pah Meto di Kabupaten Timor Tengah Selatan.

\section{c. Penanda Solidaritas dan Perekat Element Masyarakat dalam Budaya Mamat dan Tarian Bonet}

Suatu masyarakat umumnya dipersatukan oleh ikatan komunal untuk membentuk solidaritas kelompok lokal. Setiap masyarakat mempunyai media-media untuk mengikat warganya yang dapat dilakukan melalui ritual keagamaan atau upacara adat lainnya. Setiap masing-masing anggota masyarakat saling memberi dan menerima sesuai dengan bidang dan fungsinya masing-masing. Ikatan komunal masyarakat Atoni Pah Meto juga ditandai dengan berbagai aktivitas yang sering dilakukan bersama. Salah satunya aktivitas di bidang komunikasi baik secara individu maupun kelompok seperti 
tamam/budaya mamat; dan kesenian daerah seperti tarian bonet dalam berbagai acara salah satunya pesta panen.

\section{Budaya Mamat}

Dari berbagai aktivitas yang menunjukan solidaritas komunal masyarakat Atoni Pah Meto, yang paling sederhana dan selalu dilakukan adalah tradisi makan sirih dan pinang (mamat) sebagai simbol komuniakasi yang mempererat hubungan antarkomunal, sebab mamat merupakan sebuah kebiasaan mendasar ketika menyambut tamu dalam rumah. Hal itu juga diperkuat oleh Suminar (2020:56) bahwa, Budaya mamat merupakan simbol budaya yang sangat mendasar dalam kehidupan masyarakat Atoni Pah Meto, sebagaimana kebiasaan minum teh, kopi, atau merokok. Dalam tingkat sangat kecanduan, sirih pinang dijadikan prioritas sebelum makan makanan utama atau melakukan kegiatan lain. Sirih pinang adalah pembuka komunikasi dan sopan santun budaya dalam suku Atoni Pah Meto. Seluruh pertemuan tidak memiliki makna jika tanpa sirih pinang. Rasa malu dan bersalah dirasakan jika tidak tersedia sirih pinang dalam setiap rumah, terutama jika ada tamu atau keluarga datang berkunjung. Sebagaimana dalam legenda Oepunu, ditemukan bahwa pemilik pesta secara spontan menyuguhkan sirih pinang kepada semua tamu yang hadir di pestanya meskipun ada tamu yang tak diundang. Budaya mamat berlangsung tertutama ketika tamu atau keluarga berkunjung, tuan rumah wajib menyuguhkan sirih pinang atau yang diistilahkan mpuah. Seperti yang tertuang pada penggalan cerita bagian (6).

Pada penggalan cerita bagian (6), teridentifikasi budaya mamat sebagai salah satu kearifan lokal yang menunjukkan solidaritas, sekaligus sebagai perekat element antarmasyarakat. Penggambaran budaya mamat dalam praktiknya, yaitu masyarakat Atoni Pah Meto mengunya sirih baik buah maupun daun dicampur dengan pinang, tembakau, dan kapur. Namun yang paling umum adalah mengunyah sirih, pinang dan kapur hingga mengasilkan warna merah pada ronga mulut dan gigi. Dan ketika dikunyah akan menghasilkan efek psikoaktif dan kolinergik ringan. Ada banyak produksi air liur berwarna merah darah yang dapat menodai struktur mulut. Setelah bertahun-tahun mengunyah, gigi bisa menjadi merah-coklat hingga hampir hitam, (Norton dalam Suminar 2020).

Budaya mamat dapat dimaknai sebagai simbol pengikat tali keakraban, persaudaraan, kekeluargaan antarmasyarakat, selain sebagai alat komunikasi yang sangat tradisional. Ludah sirih pinang yang berwarna merah merupakan salah satu simbol kebersamaan, bahwa mereka memiliki ludah yang sama seperti darah yang sama warnanya sehingga tidak ada perbedaan di antara mereka baik suku, agama, atau komunitas dalam bentuk apa pun. Setiap orang dianggap sama dan perlu dihargai ketika berkunjung ke rumah mereka, dan bentuk penghargaan berupa penyuguhan sirih pinang atau yang disebut mpuah. Penyuguhan sirih pinang biasanya sirih, pinang, dan kapur ditempatkan pada sebuah wadah berbentuk segi empat yang terbuat dari anyaman daun lontar, dengan ukuran $10 \mathrm{~cm}$ sampai $20 \mathrm{~cm}$ persegi, lalu di letakan di atas meja yang terletak di depan tamu, atau langsung diberikan ke tamu dengan posisi pemberi menunduk atau menjongkok di tanah. Hal itu sebagai bentuk sopan dan hormat kepada tamu yang berkunjung.

\section{Tarian Bonet}

Tarian Bonet merupakan tarian khas masyarakat Atoni Pah Meto di Kabupaten Timor Tengah Selatan, dengan bentuk tarian massal berlagu. Tarian tersebut merupakan gabungan antara gerakan kaki, gerakan gandengan tangan, dengan lagu yang dinyanyikan 
secara bersahut-sahutan. Tarian bonet dilakukan dalam bentuk kelompok, dan para penari dapat melakukan kombinasi posisi antara penari laki-laki dan perempuan saling bergandengan tangan serta melingkar. Jumlah penari tidak terbatas dan selalu mengutamakan kekompakan suara, gerak dan irama untuk menciptakan keharmonisan. Keharmonisan suatu gerak dan irama dapat diamati dan disimak dari beberaa hal yaitu: syair, terdiri dari dua bentuk yakni satu orang yang menyebutkan syair disebut (atonis), dan atutas yaitu orang yang menuturkan syair dan semua peserta melagukan syair yang dituturkan; komposisi keseragaman gerak tangan dan gerak kaki, menghasilkan hentakan dan kombinasi yang sangat indah.

Seperti yang dikemukakan oleh Banusu (2020:8) bahwa, bonet sendiri secara etimologis berasal dari rangkaian kata dalam bahasa Dawan yaitu $\mathrm{Na}^{\prime}$ bonet yang artinya mengepung, mengurung, mengelilingi atau melingkari. Dalam bahasa pergaulan dari kata boen yang berarti mengelilingii dan membagi. Kata itu bersinonim dengan kata nfun atau nafun. Misalnya asu nabonet metan (anjing mengelilingi musang), tok tol bonet (duduk dalam bentuk lingkaran). Bonet dalam hal ini dimaksudkan sebagai membungkus atau dibungkus. Dalam konteks Tari bonet bisa diartikan menari dengan posisi membentuk lingkaran.

Berdasarkan penjelasan tersebut maka dapat dikatakan bahwa tarian bonet masyarakat Atoni Pah Meto mengandung nilai-nilai kehidupan yang menunjukkan adanya nilai-nilai solidaritas kelompok yang tertuang dalam bentuk kebersamaan mereka. Hal itu ditandai dengan komposisi keseragaman gerakan serta syair lagu yang dinyanyikan, menunjukan adanya hubungan dan solidaritas dalam melakukan segala aktivitas di daerahnya. Seragam menggerakan kaki dan gandengan tangan menunjukan adanya kerja sama dalam segala hal baik dalam susah maupun senang, baik permpuan maupun lakilaki harus saling bertoleransi dalam kehidupan mereka. Wujud nilai kebersamaan tarian bonet mengajarkan kepada masyarakat untuk selalu bersolidaritas dengan siapa saja yang mereka temui baik itu sesama sebagai orang asli Meto maupun pendatang dan tidak menunjukan perbedaan di mata Tuhan meskipun beda agama, dan di mata dunia meskipun beda adat dan budaya.

Tarian bonet bagi suku Atoni Pah Meto sangat digemari masyarakat pendukungnya, apalagi pada saat acara-acara pesta adat. Pesta adat yang sering diiringi dengan tarian bonet seperti, pesta panen, pesta perkawinan, pesta pengukuhan Pendeta atau penobatan kepala desa, pesta perdamaian setelah konflik, dan pesta pembuatan rumah adat. Tarian bonet dibedakan atas 4 jenis yaitu: (1) Boennitu (puji-pujian kepada arwah); (2) Boen Ba'e (Puji-pujian dalam suasana ceria) kelahiran olen, menimang anak ko'an, pada acara pesta-pesta (perkawinan, panen); (3) penyambutan tamu (futmanusefmanu); dan (4) Boenmepu (nyanyian kerja).

Tarian bonet yang teridentifikasi dalam cerita legenda Oepunu, menunjukkan adanya unsur kearifan lokal dari segi penanda solidaritas kelompok lokal, sekaligus sebagai identitas masyarakat Atoni Pah Meto yakni tarian bonet. Tarian bonet itu dilakukan dengan cara bergandengan tangan antara laki-laki dan perempuan kemudian membentuk lingkaran dengan menggerakan kaki serta maju dan mundur. Setiap hentakan kaki harus seragam bagitu pula dengan syair lagu, teriakan-teriakan kegembiraan, dan musik tradisional yang mengiringi membuat tarian itu sangat indah ditonton dan nikmati.

Tarian bonet yang dilakukan masyarakat dalam cerita, untuk menunjukan rasa syukur kepada Tuhan dan rasa bahagia terhadap hasil kebun dan ladang yang mereka peroleh. Selain itu sebagai suatu tanda pengikat persaudaraan antara mereka. Dalam tarian itu mereka menari sesuai irama musik dan lagu yang dinyanyikan kadang tidak 
terbatas waktu, karena keasyikan terkadang hingga subuh. Sama halnya dengan yang tertuang data cerita legenda Oepunu bagian (4).

Data tersebut menceritakan bagaimana orang-orang di kampung itu melakukan tarian bonet dalam pesta sehingga membuat buaya-buaya di sungai menjadi tertarik untuk hadir dalam pesta tersebut. Hal itu merepresentasikan tarian bonet bukan hanya sebagai tarian biasa tetapi mampu menarik perhatian orang lain agar dapat hadir dan turut serta dalam tarian itu. Hal itu menunjukan bahwa, solidaritas kelompok yang direkatkan dengan sebuah acara pesta panen secara tradisional dengan iringan musik gong dan tambur, nyanyian, teriakan serta tarian kegembiraan yang disebut bonet, sekaligus menjadi salah satu identitas masyarakat Atoni Pah Meto di Kabupaten Timor Tengah Selatan. Dapat disimpulkan bahwa tarian bonet memiliki makna persatuan dan kesatuan, persaudaraan, kekeluargaan, dan kebersamaan di antara masyarakat pemiliknya. Saat ini tarian bonet sering difestivalkan pada acara-acara Nasional, bahkan dijadikan objek event perlombaan antarsekolah maupun antarsuku Atoni Pah Meto itu sendiri.

\section{d. Kepercayaan Lokal}

Kepercayaan masyarakat Atoni Pah Meto bersifat keagamaan sebagaimana dikenal dengan agama kristiani dan bersifat kepercayaan lokal atau semacam mitologi. Seperti yang dikatakan Taum (2004), bahwa sekalipun mayoritas masyarakat Dawan sudah memeluk agama kristiani sebagai agama monotheis modern yang Universal, kepercayaan lokalnya masih dihayati dan dipraktikkan dalam kehidupan sehari-harinya. Hal itu sangat beralasan karena sebelum mengenal Agama modern, terlebih dahulu masyarakat Atoni Pah Meto melakukan pemujaan terhadap wujud tertinggi dan leluhur. Pemujaan terhadap agama lokal berupa wujud tertinggi disebut yang sebagai Uis Pah dan Uis Neno.

Uis Neno adalah wujud penguasa langit atau Tuhan yang ada di langit, sedangkan Uis Pah adalah penguasa alam atau Tuhan bumi. Kedua bentuk kepercayaan lokal masyarakat Atoni Pah Meto tersebut dapat diartikan secara etimologis yakni: Uis Neno terdiri atas dua kata, Usif(Raja/Tuhan/Penguasa) dan Neno (Langit/Tertinggi); demikian pula dengan Uis Pah, terdiri atas dua kata, Usif (Raja/Tuhan/Penguasa) dan Pah (Tanah/alam/bumi). Uis Neno berarti Tuhan Langit, sedangkan Uis Pah berarti Tuhan Bumi. Kepercayaan lokal masyarakat Atoni Pah Meto terhadap Uis Neno dan Uis Pah selalu berkaitan dengan segala unsur kehidupan masyarakatnya. Seperti yang terepresentasi dalam legenda Oepunu.

Legenda Oepunu menceritakan empat suku (Tusi, Tano, Leobenu, Ama Bansoma) di desa Billa yang melakukan pesta panen untuk mensyukuri hasil panen padi dari kebun dan ladang mereka terhadap Uis Pah dan Uis Neno. Masyarakat tersebut beranggapan bahwa hasil panen memuaskan dan dapat memenuhi kabutuhan pangan mereka selama setahun, oleh berkat dan izin dari Uis Neno dan Uis Pah. Hal itu pun didasari atas tradisi onen pah (ritual meminta izin dan berkat dari Uis Neno dan Uis Pah) yang dilakukan ketika masyarakat mengawali proses berkebun, bersawah, maupun berladang. Sehingga ketika memanen, mereka perlu mensyukurinya. Seperti yang tertuang dalam penggalan cerita bagian (2).

Pada penggalan cerita bagian (2), menunjukkan adanya unsur kearifan lokal dari segi kepercayaan masyarakat Atoni Pah Meto, sekaligus sebagai element perekat lintas masyarakat pemiliknya. Hal itu ditandai dengan pengadaan pesta panen oleh keempat suku, yang menghadirkan anggota keluarga dan tamu-tamu lainnya untuk bersama-sama mensyukuri hasil kebun, sawah, dan ladangnya. 


\section{e. Marga sebagai Penanda Identitas Masyarakat Atoni Pah Meto}

Nama marga atau suku menunjukkan identitas pemiliknya berasal. Penyebutan dan penggunaan nama panggilan seseorang dalam percakapan akan sangat menentukan bagi proses pembentukan identitas seseorang dalam suatu kelompok atau masyarakat (Novianti, 2016:314). Sementara marga merupakan petunjuk identitas keturunan, identitas diri, indentitas asal daerah dan kampung, dan identitas nenek moyang (Harahap, 2019: 630-631). Marga merupakan nama keluarga atau keturunan yang lazimnya dicamtumkan di bagian belakang nama diri. Terkait marga, masyarakat Atoni Pah Meto di Kabupaten Timor Tengah Selatan, memiliki pola susunan patrilineal, yakni marga sang suami yang diturunkan kepada anak-anak sebagai keturunan biologisnya.

Marga menjadi penciri masyarakat Atoni Pah Meto, seperti Marga Tusi, Tano, Leobenu, dan Ana Bansoma yang terepresentasi dalam cerita legenda Oepunu. Keturunan dari empat marga itu, tersebar di wilayah daratan Timor, dan khususnya di Kabupaten Timor Tengah Selatan. Hal itu terdapat dalam data cerita legenda Oepunu bagian (1). Sebelum peristiwa mengerikan terjadi, empat marga dan keluarganya bermukim di Kecamatan Amanuban Timur, namun setelah peristiwa naas itu terjadi mereka yang masih hidup memutuskan untuk pindah ke Kono di Kecamatan Amanuban Selatan. Namanama marga itu sekaligus menjadi penanda identitas dan termasuk salah satu unsur kearifan lokal masyarakat Atoni Pah Meto di Kabupaten Timor Tengah Selatan.

\section{f. Latar Tempat dan Peninggalan (Faut Esu)}

Latar dalam legenda Oepunu berupa latar tempat. Latar tempat merupakan latar yang memberikan gambaran sekaligus penjelasan mengenai tempat lokasi, wilayah, atau daerah terjadi peristiwa dalm cerita, (Hadiansah, 2019:51). Latar dalam kajian ini difokuskan pada tempat-tempat yang terdapat dalam cerita, di antaranya: nama tempat Oekbiti di Desa Billa berubah nama menjadi Oepunu setelah peristiwa pembantaian yang dilakukan oleh buaya atau yang disebut Uis Oe (Raja Air) terhadap manusia dan ternak peliharaan masyarakat di tempat tersebut; nama tempat Putu, merupakan tempat yang tidak jauh dari Oepunu, dan terletak di bukit dekat kolam dan persawahan; nama tempat Kono muncul usai peristiwa pembantaian dan keluarga yang hidup memutuskan untuk pindah ke sana. Kono terletak di Kecamatan Amanuban Selatan, Kabupaten Timor Tengah Selatan.

Nama-nama tempat yang digambarkan pada cerita Oepunu, merupakan namanama tempat yang bersifat onomatopetis dan berasosiatif dengan peristiwa-peristiwa, bentuk, yang mendasarkannya. Nama-nama tempat itu menunjukkan identitas atau lokalitas masyarakat Atoni Pah Meto yang bermukim di Kecamatan Amanuban Timur dan Kecamatan Amanuban Selatan. Nama tempat Oekbiti jika diartikan dalam bahasa Meto, yaitu berasal dari dua kata yakni oe (air) dan kbiti (kala jengking) sehingga menjadi eokbiti (air kala jengking), nama tempat itu berubah menjadi Oepunu (air busuk) usai peristiwa yang diceritakan dalam legenda Oepunu, seperti yang terdapat pada data cerita bagian (1).

Faut Esu (batu lesung) sebagai peninggalan atau bukti tertancapnya gigi buaya masih tersimpan di Oepunu bekas pemukiman keluarga Tusi, Tano, Leobenu, dan Ana Bansoma. Faut esu kini dijadikan bukti sejarah dari legenda Oepunu. Seperti yang tergambarkan pada data bagian (14) dan (15). 


\section{Simpulan}

Hasil penelitian menunjukan adanya unsur kearifan lokal masyarakat Atoni Pah Meto dalam legenda Oepunu, diantaranya: pengetahuan meramal yang disebut mnane; hasil keterampilan berupa esu (lesung) sebagai peralatan mengelola bahan makanan, mau dan tais (kain tenun); penanda solidaritas dan elemen perekat antarmasyarakat lokal dalam tarian bonet dan budaya mamat (makan sirih pinang); kepercayaan terhadap Uis Neno (Penguasa langit) dan Uis Pah (Penguasa alam); marga (Tusi, Tano, Leobenu, Ana Bansoma) sebagai penanda identitas; latar tempat (Oekbiti, Putu, Oepunu, Kono), dan peninggalan berupa faut esu (batu lesung) yang masih tersimpan di Oepunu, Desa Billa, Kecamatan Amanuban Timur, Kabupaten Timor Tengah Selatan. Manfaat dari penelitian ini dapat berimplikasi bagi tatanan kehidupan masyarakat Atoni Pah Meto pada umumnya. Hasil kajian ini juga dapat dijadikan bahan apresiasi bagi kalangan pendidik, maupun pelajar di sekolah-sekolah, bahkan di Perguruan Tinggi. Terkait dengan ilmu sastra lisan, hasil kajian ini dapat berguna sebagai bahan referensi tambahan bagi peneliti-peneliti selanjutnya yang berniat meneliti penelitian serupa.

\section{Ucapan Terima Kasih}

\section{Daftar Pustaka}

Banusu, Yeremias. (2020). Korelasi Makna Tarian Bonet Masyarakat Dawan dengan Konsep Relasi Martin Buber (Sebuah Studi Komparasi dengan Pendekatan Filosofis). Ambon: Jurnal Teologi Kontekstual, Volume 5, Nomor 2.

Danandjaja, James. 2007. Foklor Indonesia, Ilmu Gosip, Dongeng dan lain-lain. Jakarta: Pustaka Utama Grafiti.

Haba, John. 2007. "Revitalisasi Kearifan Lokal: Studi Resolusi Konflik di Kalimantan Barat, Maluku dan Poso," dalam Irwan Abdullah, dkk. (ed.), Agama dan Kearifan Lokal dalam Tantangan Global. Yogyakarta: Pustaka Pelajar.

Hadiansah, D. 2019. Kajian Struktural dan Nilai Kearifan Lokal Sunda dalam Novel Prabu Siliwangi Karya E. Rokajat Asura serta Pemanfaatannya sebagai Bahan Ajar Sastra di SMA. Wistara: Jurnal Pendidikan Bahasa dan Sastra, 2(1), 46-57.

Harahap, A. S. 2019. Kajian Hukum Islam terhadap Pelaksanaan Perkawinan Menurut Prosedur Pranata Marga pada Masyarakat Padang Bolak. Dalam Prosiding Seminar Nasional Hasil Penelitian (Vol. 2, No. 1, pp. 628-634).

Indrastuti, Novi Siti Kussuji. 2018. Representasi Unsur Budaya dalam Cerita Rakyat Indonesia: Kajian Terhadap Status Sosial dan Kebudayaan Masyarakat. Malaysia: Malaysian Journal of Social Sciences and Humanities (MJSSH), Volume 3, Issue 3, (page 189 - 199).

Maulidiah, Nurfitriana dan Kundharu Saddhono. 2019. Wujud Budaya dan Nilai Pendidikan dalam Cerita Rakyat Putri Jelumpang: Sebuah Kajian Antropologi Sastra: Jurnal Ilmiah Widyaparwa, Volume 47, Nomor 2.

Novianti, M. I. 2016. Penggunaan Pelesetan Nama Panggilan Dalam Masyarakat Sasak Dan Relevansinya Dalam Pembelajaran Bahasa Indonesia di SMA. RETORIKA: Jurnal Ilmu Bahasa, 2(2), 313-327.

Nuraeni, H. G \& Muhammad Alfan. 2013. Studi Budaya di Indonesia. Bandung: Pustaka Setia. 
Nurjanah dan Yurdayanti. 2019. Representasi Kearifan Lokal Masyarakat Bangka dalam Cerita Rakyat Bandar Akek Antak: Jurnal Sirok Bastra Vol. 7, Nomor 2.

Rusyana, Yus, dkk. 2000. Prosa Tardisional: Pengertian, Klasifikasi, dan Teks. Jakarta: Pusat Bahasa Depertemen Pendidikan Nasional.

Semi, Atar. 2008. Stilistika Sastra. Padang : Universitas Negeri Padang Press

Sibarani, Robert. 2014. Kearifan Lokal Hakikat, Peran, dan Metode Tradisi Lisan. Jakarta: Asosiasi Tradisi Lisan.

Siswanto, Wahyudi. 2008. Pengantar Teori Sastra. Jakarta: Grasindo

Siyono. 2014. Kearifan Lokal dalam Sastra Lisan Suku Moy Papua. Surabaya: Jurnal Atavisme Volume 17, Nomor 1.

Sudikan, Setya Yuwana. 2013. Kearifan Budaya Lokal. Sidoarjo-Jawa Timur: Damar Ilmu.

Sudikan, Setya Yuwana. 2001. Metode Penelitian Sastra Lisan. Surabaya: Citra Wacana.

Suminar, Erna. (2020). Simbol dan Makna Sirih Pinang bagi Masyarakat Atoni Pah Meto di Timor Tengah Utara. Bandung: Jurnal Komunikasi dan Bisnis Volume 8, Nomor 1.

Taum, Yoseph Yapi, dkk. 2004. Bahasa Merajut Sastra Merunut Budaya. Yokyakarta: Universitas Sanata Dharma

Tussaadah, Nurlaela dkk. 2020. Analisis Puisi "Rahasia Hujan" Karya Heri Isnaini dengan Menggunakan Pendekatan Mimetik. Jurnal Parole Volume 3 Nomor 3. 